inOedia $\quad \begin{aligned} & \text { InMedia } \\ & \text { The French Journal of Media Studies }\end{aligned}$

$1 \mid 2012$

Global Film and Television Industries Today

\title{
Ars Industrialis, arsindustrialis.org
}

Association internationale pour une politique industrielle des technologies de l'esprit / International association in favour of an industrial policy for the technologies of the mind

\section{Frédérique Mingant}

Translator. Cecilia Tirtaine

\section{CpenEdition}

\section{Journals}

Electronic version

URL: http://journals.openedition.org/inmedia/159

DOI: 10.4000/inmedia.159

ISSN: 2259-4728

Publisher

Center for Research on the English-Speaking World (CREW)

Electronic reference

Frédérique Mingant, « Ars Industrialis, arsindustrialis.org », InMedia [Online], 1 | 2012, Online since 16 March 2012, connection on 21 September 2020. URL : http://journals.openedition.org/inmedia/159 DOI : https://doi.org/10.4000/inmedia.159

This text was automatically generated on 21 September 2020

(c) InMedia 


\title{
Ars Industrialis, arsindustrialis.org
}

\author{
Association internationale pour une politique industrielle des \\ technologies de l'esprit / International association in favour of an \\ industrial policy for the technologies of the mind
}

\section{Frédérique Mingant}

Translation : Cecilia Tirtaine

1 The arsindustrialis.org website was created in 2005, when the association Ars Industrialis came into being. The association was founded by a group of philosophers and jurists, on the initiative of philosopher Bernard Stiegler, the former director of the IRCAM (Institut de Recherche et Coordination Acoustique/Musique-Institute of Research and Coordination on Acoustic/Music) and the current director of the Department of cultural development at the Centre Georges Pompidou (French National Arts Centre).

2 The main focus of the association-cultural and philosophical but equally political and militant-is to study and find new ways of fighting against what it sees as the new "technologies of the mind" (or "psychopower," a concept which echoes Michel Foucault's "biopower"). Its argument is that the life of the mind was, during the $20^{\text {th }}$ century and due to the pressure of mass consumption, subjected to economic imperatives, and therefore to the imperatives of the cultural industries, by means of the computing and telecommunications industries. The "technologies of the mind" are thus composed of all the techniques which were set up, via telecommunications, in order to make people buy, and, at a deeper level, make them yearn for goods and services. This implies developing a whole battery of techniques which target people's brains. Eventually, this has resulted in a shorter and shorter attention span, a lack of longing, an increasing difficulty in individuating (that is to say the process which makes us individuals, distinct from our neighbours), a growing disappearance of the caring about oneself, a way of addressing the short-term which is alarming, and continual promotion of impulse (immediacy, brutality, violence, non-memory) at the expense of libido (which implies time, construction, memory). This critique of consumer society was inspired by several authors: Gilbert Simondon, André LeroiGourhan, Bertrand Gille, Jean-Jacques Rousseau, Martin Heidegger, Jacques Derrida, 
Edmund Husserl, Michel Foucault and Emmanuel Kant, for its philosophical dimension, and Sigmund Freud (theory of impulses and impulsiveness), Theodor W. Adorno, Herbert Marcuse and Michel Foucault, for the socio-critique of the media and marketing.

3 The struggle, as seen by Ars Industrialis, is to reclaim those new means of communication and to study the "technologies of the mind" pertaining to them, in order to develop new mental "weapons"-such as regaining one's attention, the capacity to decode and analyse information, etc.-, but also develop other means of using those new tools and thus develop new ways of relating to the other, so that people-seen as thinking beings with longings-become human beings again and not unfulfilled consumers.

$4 \quad$ Media analysis is conducted in different ways by Ars Industrialis and has been evolving over the years as techniques were evolving. Bernard Stiegler has thus devoted several articles, lectures or books to the issue of television, ${ }^{1}$ particularly in relation to children, their development (their capacity to be attentive, to build shared knowledge, etc.) and to the notion of transmission. More generally, the association's philosophical (philosophy of techniques, of individuation, of knowledge and of perception) and especially economic and social reflection is mostly based on the observation of new technologies (the Internet, social networks, nanotechnologies). A significant part of its work consists in studying these new technologies: What are they? What do they allow us to do? How are they used? How can they be used without being "psychopowers"? In what ways do they change our relationship to the other, to knowledge, to communication, to information?

5 The website, in addition to giving higher visibility to the association and its actions, aims to be a model of this new system which it advocates and which it calls "the economy of contribution" (as is the case, for example, with Wikipedia): its users are consumers but also contribute articles. They can benefit from everyone's abilities. As a matter of fact, Ars Industrialis regularly calls for contributions from its members, on specific subjects. ${ }^{2}$ Three workshops currently exist, each respectively devoted to "technologies of the self"-a concept created by Michel Foucault, which includes all the technologies of self-writing-, "relational technologies"-i.e. writing, communication technologies, social networks, etc.-, and, precisely, the issue of the "economy of contribution."

$6 \quad$ Ars Industrialis regularly proposes debates, which often take place at the Théâtre de la Colline in Paris. In the past four years, the association has organised seminars at the Collège International de Philosophie, under the broad title "Finding New Weapons-For a Polemology of the Mind." And, in line with a real economy of contribution, the website has a wealth of textual as well as sound and video archives: many debates or lectures are filmed or podcasted. The website's home page consistently gives the latest news about Ars Industrialis and has an inset video of the latest debates, such as the debate of 19 March 2011, which focused on relational technologies, or that of 15 January 2011, which dealt with the theme of "care and relationships."

Contents of the website:

- A calendar of the different events organised by Ars Industrialis (debates, thematic days, workshops and work groups, etc.)

- The 2005 Manifesto, which led to the creation of the association, as well as the 2010 Manifesto, which reinterprets the former Manifesto, taking into account the changes which 
occurred since 2005. The two Manifestos are translated into several languages, including English.

- Web pages devoted to Bernard Stiegler. In addition to a detailed biography and bibliography, these pages contain a wealth of archives, including many of the lectures delivered by Bernard Stiegler in the past five years: written texts, videos and audio pieces. Some texts are the transcriptions of conferences given by Bernard Stiegler in several European countries and in the United States and are thus available in English.

- Generally, many textual, video and sound archives of events organized by Ars Industrialis.

- A glossary which gives the definitions of the words often used by members of Ars Industrialis.

\section{NOTES}

1. Bernard Stiegler, Serge Tisseron, Faut-il interdire les écrans aux enfants? (Paris : Mordicus, 2009) ; Bernard Stiegler, La Télécratie contre la démocratie - Lettre ouverte aux représentants politiques (Paris : Flammarion, 2006) ; Jacques Derrida, Bernard Stiegler. Echographies de la télévision, entretiens filmés (Paris : coll. Débats, Galilée-INA, 1996).

2. The association currently has around 500 members, from different countries (mostly European). Membership is open to anyone, which means that contributions are not necessarily made by specialists - they can be, but this is not the association's main aim.

\section{AUTHORS}

\section{FRÉDÉRIQUE MINGANT}

Compagnie $13 / 10^{\mathrm{e}}$ en Ut

http://www.1310.fr/ 